\title{
沖縄県宮古島における雲と天空紅斑紫外放射照度・輝度変化に関する研究 VARIATION OF SKY ERYTHEMA ULTRAVIOLET IRRADIANCE \& RADIANCE BY CLOUD IN OKINAWA MIYAKO ISLAND
}

\author{
川西利昌*1, 大塚文和*2 \\ Toshimasa KAWANISHI and Fumikazu OTSUKA
}

\begin{abstract}
Ultraviolet radiation may cause the skin damage. In order to protect skin from harm, it is necessary to know sky ultraviolet radiation. Until now, sky ultraviolet radiance distribution has been measured using mechanical scanning method. This has the problems that cloud condition may happen to change in a few minute during measuring. New measuring equipment for radiance distribution of sky erythema ultraviolet radiation was developed. It was an electronic scanning method and is equipped with 145 sensors of erythema ultraviolet radiation. Therefore, it has become possible to measure the radiance distribution at only three seconds. This research aims to measure erythema ultraviolet radiance distribution under broken cloud sky condition using this measuring equipment. As results, it was clarified ultraviolet radiation from broken cloud sky is sometimes higher than one from clear sky.
\end{abstract}

Keywords: Radiance, Sky, Erythema, Ultraviolet, Broken cloud 放身輝度,天空,經玟,紫外線, 雲

\section{1. 緒論}

雲一つ無い快晴より一部に雲が有った方が、紫外放射照度が増加 することが Estupinan、Crawford, 高野、垂水らによって報告されて いる。Estupinan は雲による日射と紫外放射の減衰及び増加を述べ 1), Crawford は天空魚眼写真と紫外放射照度を時系列で並心゙, 快晴 時より雲が出現した方が、紫外放射照度が増加する様子を記してい る ${ }^{2)}$ 。垂水は金沢における紫外放射測定から、“雲の全く無い晴天時 よりも多少の雲や上層雲が出現している方が反射等の影響により地 上到達紫外線量が増大寸る”と推察している ${ }^{3)}$ 。また高野は、“雲量 が 5〜6 を境とし, それ以下の場合紫外放射の観測值が、標準值を上 回る例が多く出現寸る、これは雲間における雲反射光の増加や雲内 部の雲散乱光の増加によるものと推測される”と述べている ${ }^{4)}$ こ れらはいずれも天空全体による紫外放射照度について論じたもので、 天空要素の紫外放射輝度について触れられていないため、どこにあ る雲によって紫外放射照度が増加したか不明である。

Weihs らは broken cloudによる紫外放射輝度は快晴時の 2.5 倍に 達することがあるとしている5 ${ }^{5)}$ 、た Kuchinke らはセンサを円筒で 囲み上下させて立体角を変化させ、雲による紫外放射照度の変化を 検討しているが、いずれも個々の雲の影響は述べていない。この他、
可視光領域では雲と天空輝度分布について井川 ${ }^{7)}$, 中山 ${ }^{8)}$ ら多くの 論文が有る。

現在天空放射輝度測定に多く使われている機械走查式天空放射輝 度測定装置では、145 天空要素の走查時間が最短でも 2 分近くかか り、雲の個々の動きに追従できない。本研究分野ではWeihs らがフ アイバー先端を機械で走査させ、ファイバー出力端に分光器を接続 して、天空の紫外放射輝度を取得しているが、天空全体の走查に 15 分要している ${ }^{9)}$ 。本研究で使用した電子走查式天空紅斑放射輝度測 定装置では 3 秒間隔で 145 要素の紅斑紫外放射輝度を同時測定でき、 雲の変化を研究対象とするには最適である注1)。著者らは本装置を利 用した研究により、機械走查式とは高高度の天空要素紅斑紫外放射 輝度で $20 \%$ から 30\%程度測定結果が異なること ${ }^{10)}$ 、また沖縄県石垣 島における天空状態と紅斑紫外放射輝度の関係について明らかにし てきた ${ }^{11)}$ 。

本研究は、紫外放射が最も強くなる夏至太陽高度 80,90 度、南中 時に、沖縄県宮古島で紅斑紫外放射照度・紅斑紫外放射輝度測定を 行い、雲の存在による紫外放射への影響を論じたものである。測定 の結果、雲の存在による紅斑紫外放射照度及び紅斑紫外放射輝度の 増加を確認できたので報告する。本論文の展開は、まず空全体の変
*1 日本大学理工学部海洋建築工学科 特任教授. 工博

*2 日本大学理工学部海洋建築工学科 助教·工博
Prof., Nihon University, Dr. Eng. Assist. Prof., Nihon University, Dr. Eng. 
化を紅斑紫外放射照度で捉え、雲量・紅斑紫外放射散乱率との関係 を記し、雲による紅斑紫外放射照度の変化を時刻歷で表した。次に、 雲の影響を局所的に捉えるため、紅斑紫外放射輝度からどの位置の 天空要素で雲により大きく変化するか述べている。

\section{2. 紅斑紫外放射の測定}

測定には、全天紅斑紫外放射照度計、天空紅斑紫外放射照度計、 天空紅斑紫外放射輝度分布測定装置、天空魚眼カメラを用いた。 同紅斑紫外放射照度計及び紅斑紫外放射輝度計は、センサとして ALGAN UVPD-300T046BS を採用している。図 1 に全天空及び天空紅 斑紫外放射照度計、図 2 に電子走査式天空紅斑紫外放射輝度分布 測定装置を示す。同装置及び校正法については既報文 ${ }^{10) 、 11) ~ に て ~}$ 報告した。紅斑紫外放射照度、紅斑紫外放射輝度の測定間隔は 3 秒 である。天空の撮影はデジタルカメラと Fit 画角 180 度魚眼レンズ を用い 10 秒間隔で行った。

測定場所は沖縄県宮古市平良下里 216-1 でパイナガマビーチ付 近、北緯 24 度 48 分, 東経 125 度 16 分である。測定は紫外放射 の最も強くなる夏至、2012 年 6 月 26 日から 7 月 2 日まで 7 日間 で、南中の太陽高度は約 90 度に達する。7 日間の取得紅斑紫外 放射照度データ数は 126,924 、紅斑紫外放射輝度データセットは 63, 462、データ数は 9, 201, 990、天空魚眼写真は 19, 162 枚であ る。

\section{3. 紅斑紫外放射照度}

\section{1 全天紅斑紫外放射照度の時刻歴}

図 3 は 6 月 27 日から 7 月 2 日の全天紅斑紫外放射照度の時刻歴 である。宮古島は暖流中に存在する島で、太陽が昇ると大地を暖め、 空気を上昇させて雲を発生させる。午前中の早い時間を除き、快晴 は少ない。常に上空に独立した雲が多数存在し、かつ早い速度で移 動する。したがって天空の状態は時々刻々変化し、紅斑紫外放射照 度も激しく変化する。6 月 30 日は 12 時過ぎに雨天となったため測 定を中止した。

全天、天空紅斑紫外放射照度データの内、雲の存在による紫外放 射の増加を検証するために図 4 を載せた。採用した測定值は次の条 件による、すなわち、(1)紫外放射の大きい、太陽南中を中心として 前後 2 時間以内、(2)快晴及び晴天で雲量 6 以下、(3)晴天から快晴、 またはその逆、と天空の状態が変化する、(4)太陽及びその近傍を移 動する雲がある。太陽高度の移動による紅斑紫外放射量の変化を最 小限にするため、10 分以内、(5)太陽を遮蔽する雲が無いか、雲が太 陽を遮蔽しても短時間で終わる。以上の条件で抽出した全天紅斑紫 外放射照度の時刻歴結果 10 ケースを図 4 に示寸。各図上部の魚眼写 真は左から右へ時間が経過していく。

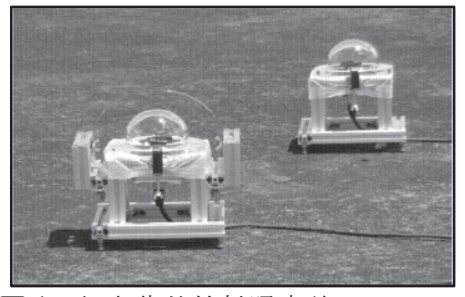

図 1 紅斑紫外放射照度計 (左：天空、右：全天)

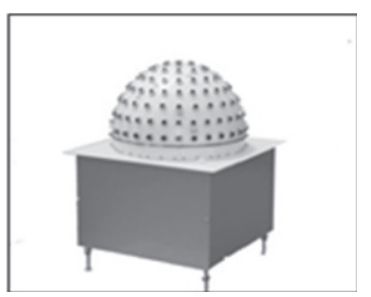

図 2 電子走査式天空紅斑 紫外放射輝度分布測定装置
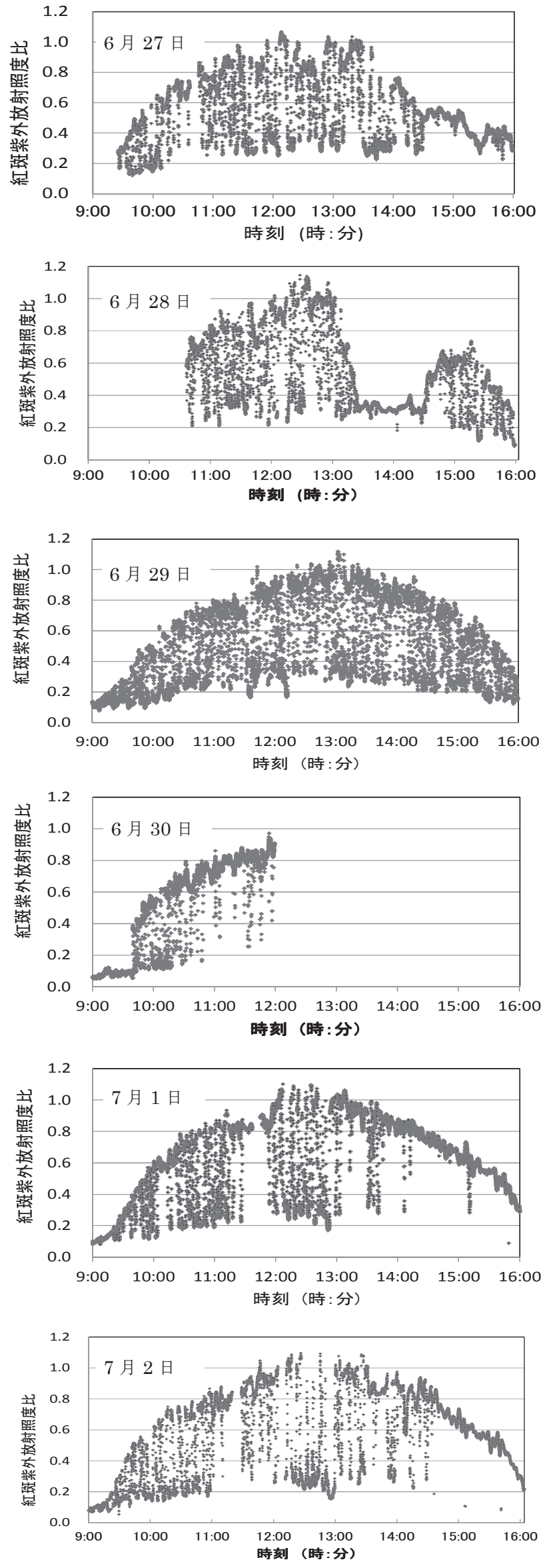

図 3 紅斑柴外放射照度の時刻歴 
(1) 快晴、雲量小

(1) 6 月 27 日
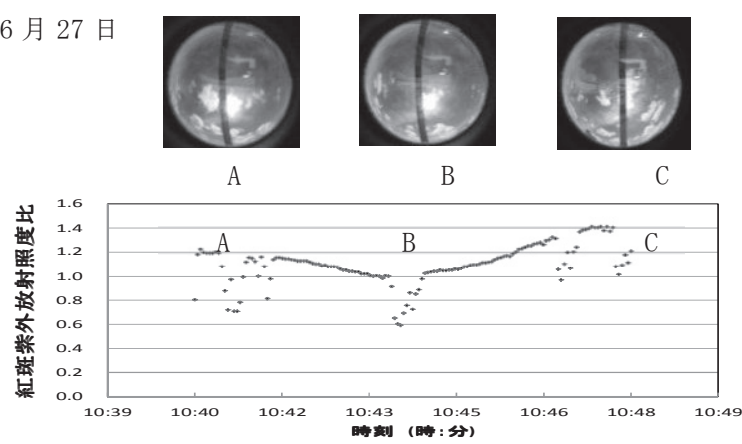

(2) 630 日
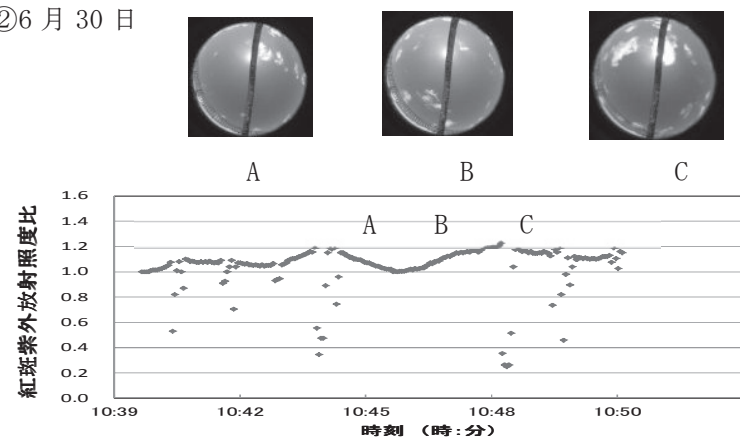

(3) 6 月 30 日
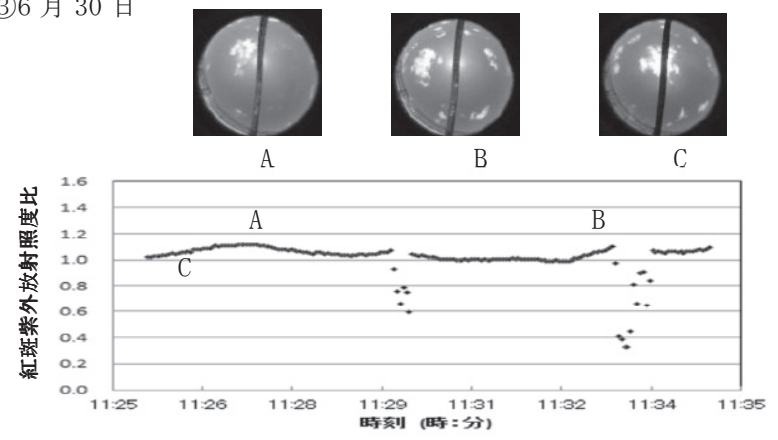

(4) 6 月 30 日
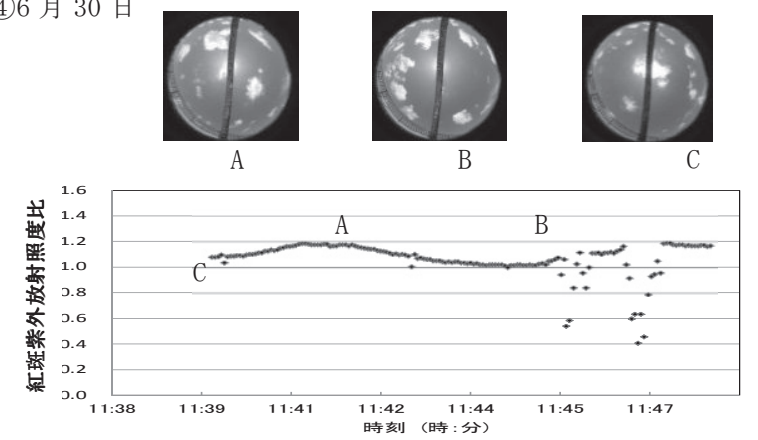

(5) 7 月 1 日
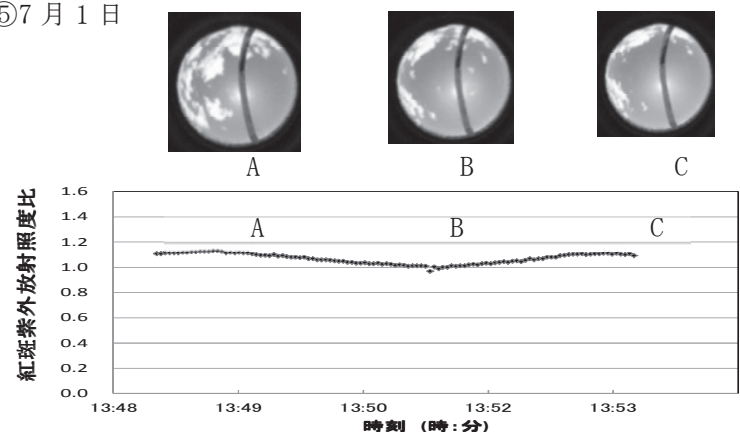

図 4 紅斑紫外放射照度の変化と天空魚眼写真

(2) 晴天、雲量中

(6) 628 日
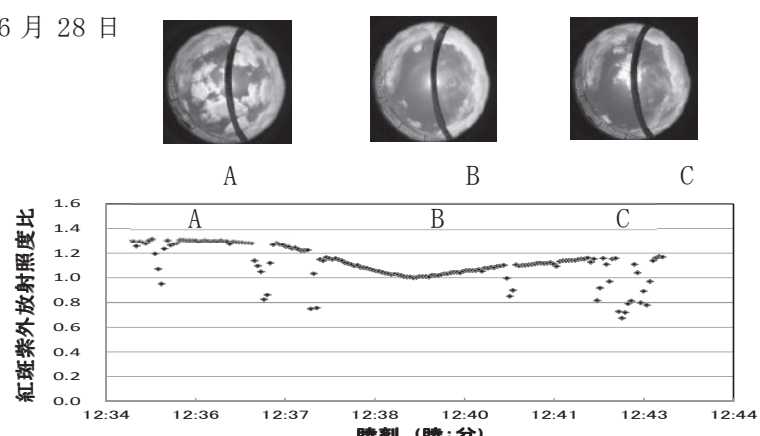

(7) 6 月 29 日
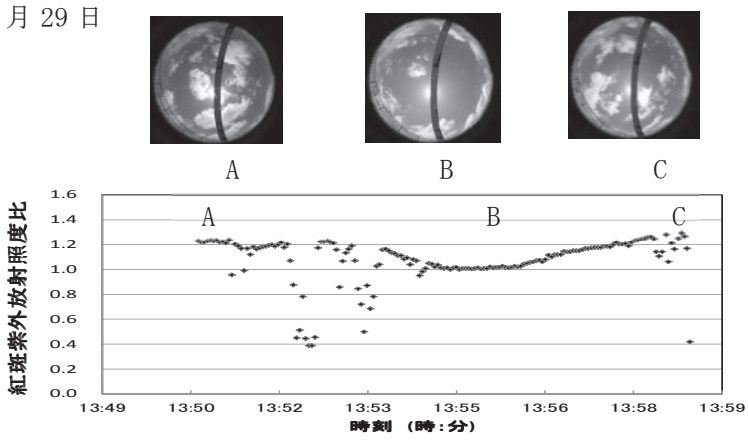

(8) 6 月 30 日
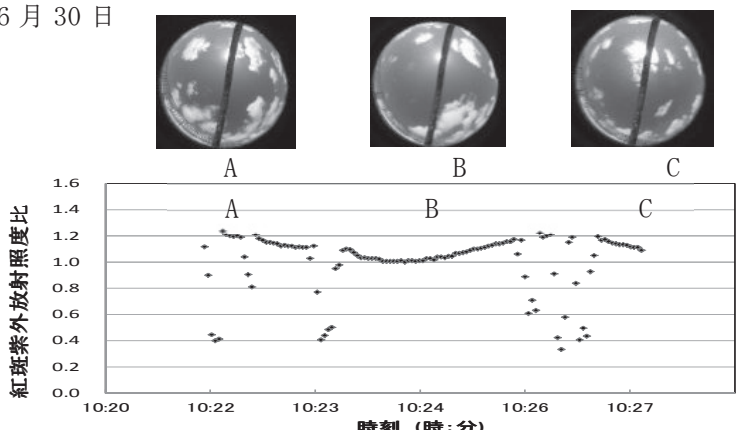

(9) 7 月 2 日
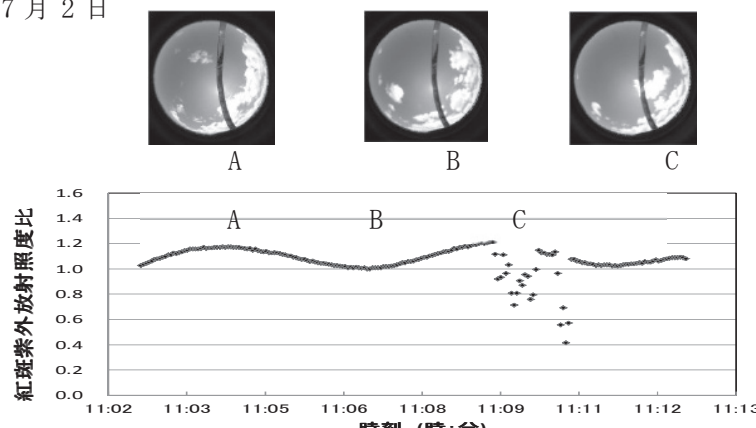

(10) 72 日
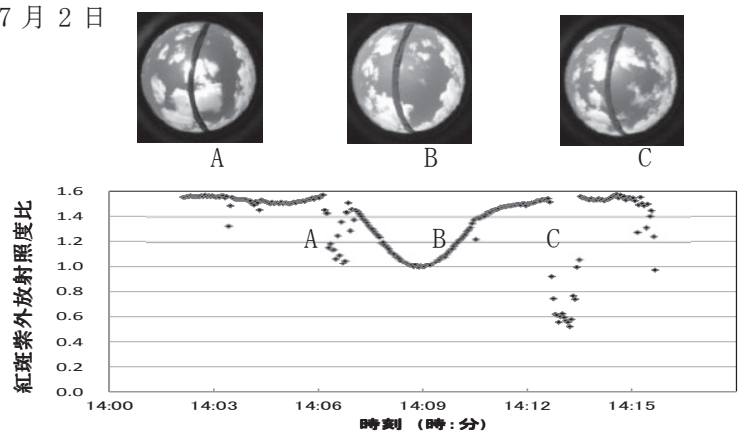
写真中央を上下に横切る黒い帯は魚眼カメラレンズの上にある太 陽遮蔽帯である。太陽及びその近傍と天空の輝度差が極めて大きい ために取り付けて、太陽を遮断し、雲の状態がよく観察できるよう にしてある。魚眼写真の左右が南北で、上下が西東である。Estupinan の研究に倣い、グラフの縦軸は当該時間内の雲無し快晴時の全天紅 斑紫外放射照度で基準化してある ${ }^{12)}$ 。横軸は時刻である。図中の A, B, C は上の写真と連動している。A は太陽の周辺に雲が有る状態、 B は太陽周辺に雲が少ない状態、C は再び雲が増加する状態である。 通常 B の時快晴に近づき紅斑紫外放射照度が低くなる。

図 4 は、（1）雲量 0,1 の快晴、（2）雲量が 2 から 6 程度の晴天、に 分類し、日付順に並べてある。図中、急激に紅斑紫外放射照度が増 減しているのは太陽に雲がかかり太陽直達を遮蔽しているためであ る。図 4 の(1)から(5)は快晴で雲が少ないと紅斑紫外放射照度の変化 も少ない。(6)から (10)のうに雲が多いほど、紅斑紫外放射照度の変 化は大きい。(10の場合、雲の移動で快晴時より最大 1.6 倍変化して いる。

\section{2 全天紅斑紫外放射照度と紅斑紫外放射散乱率}

図 5 は 2012 年 6 月 27 日から 7 月 2 日の 6 日間、 9 時から 15 時ま での 3 秒間間隔の紅斑紫外放射照度比と紅斑紫外放射散乱率を示寸。 縦軸の紅斑紫外放射照度比 $\mathrm{E}_{\mathrm{u}}$ とは、測定期間中の太陽南中時、雲無 し快晴の最大紅斑紫外放射照度で各時刻の紅斑紫外放射照度を除し た值である注 2)。横軸の紅斑紫外放射散乱率 E とは、天空紅斑紫外放 射照度をEs、全天紅斑紫外放射照度をEa とすると、

$$
\mathrm{E}=\mathrm{Es} / \mathrm{Ea} \times 100 \quad(\%)
$$

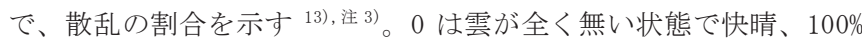
は全天雲に覆われた状態を意味する。5 日間の測定值の傾向は二つ に別けられる。6 月 27 日、28 日は紅斑紫外放射散乱率が $30 \%$ 以上で 快晴の少ない測定值群と云える。紅斑紫外放射散乱率が 100\%、寸な わち全天を雲が覆っている時、紅斑紫外放射照度比は $0.1 \sim 0.5$ であ る。各紅斑紫外放射散乱率に対する紅斑紫外放射照度比の変化は雲 や大気の変化によって起こり、6月 30 日以降に比較して小さい。一 方、6月 30 日、7 月 1 日、2 日は紅斑紫外放射散乱率が $20 \%$ 以上で、 快晴に近い測定值が多くあり、30\%付近が最大值となる。全体として 鳩の姿に似ている。各紅斑紫外放射散乱率の紅斑紫外放射照度比が 大きく変化するのは、雲の状態の変化が大きいためと考えられる。 紅斑紫外放射散乱率が $50 \%$ 以上、紅斑紫外放射照度比 0.2 以下で、 不規則な模様が見られるが、太陽を覆う雲により太陽直達が短時間 遮られる状態である。

紅斑紫外放射照度比の最大值を追っていくと、快晴近い紅斑紫外 放射散乱率 $20 \%$ 付近は天空に雲が少なく、雲からの反射や散乱が少 ないため紅斑紫外放射照度比は小さい。雲が少し出現し紅斑紫外放 射散乱率が $25 \%$ から $35 \%$ になると雲からの反射や散乱が最大となり、 紅斑紫外放射照度比は 1 を越え最大となる。更に雲が増して紅斑紫 外放射散乱率が $40 \%$ 以上大きくなると、紅斑紫外放射照度比は指数 関数的に減少し、全天を雲が覆う紅斑紫外放射散乱率 100\%で紅斑紫 外放射照度比は最小となる。本測定により雲が一部に存在すると、
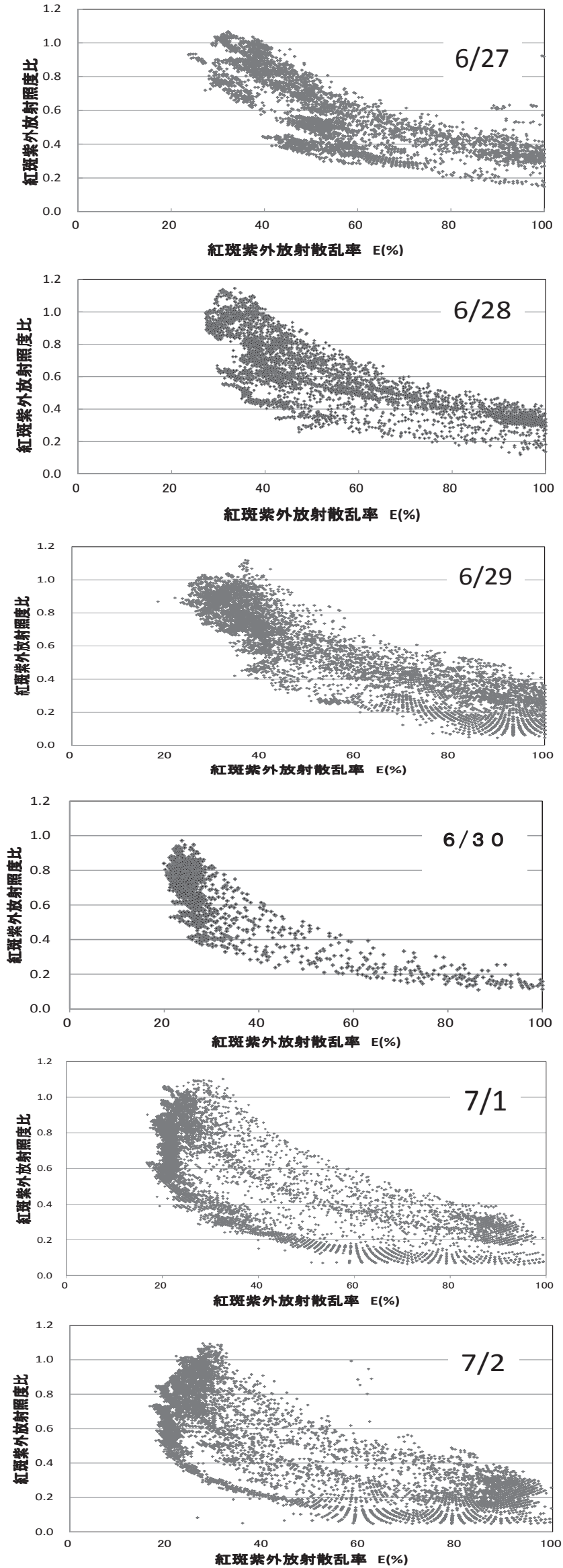

図 5 紅斑紫外放射照度比と紅斑紫外放射散乱率 
紅斑紫外放射照度が増加することが確認できた。同じ紅斑紫外放射 散乱率 $30 \%$ であっても、紅斑紫外放射照度比が 1.1 から 0.25 と幅広 く変化する。紅斑紫外放射散乱率のばらつきが大きくなるのは $25 \%$ から $60,70 \%$ 迄で、この範囲で天空の状態、雲の量、移動が極めて 複雑になる。4 日間の測定值 30,565 を基に、紅斑紫外放射照度比 $\mathrm{E}_{\mathrm{u}}$ と紅斑紫外放射散乱率 $\mathrm{E}$ の関係を実験式で表現すると次式になった。 $\mathrm{E}$ の上付き添え字括弧内の第 1 項は雲の反射による紅斑紫外放射の 増加を、第 2 項は雲の広がりによる減衰を意味する。式の最後部の 定数項は、完全曇天時の紅斑紫外放射である。

$$
\mathrm{E}_{\mathrm{u}}=\mathrm{a} \cdot \mathrm{E}^{(1-\mathrm{b} \cdot \mathrm{E})}+\mathrm{c} \quad(20>\mathrm{E}>100)
$$

全測定值から回帰計算を行って $a=0.049 、 b=0.011 、 c=0.25$ を得た。 測定值との相関係数は 0.71 である。本式を計算すると紅斑紫外放射 散乱率が $100 \%$ すなわち全天雲で覆われているときは紅斑紫外放射 照度比が 0.28 となり快晴時の約 3 割である。また快晴に近い $20 \%$ で は 0.76 となり約 8 割である。

また紅斑紫外放射照度比の最大值のみを用いて係数を算出すると $a=0.065 、 b=0.008 、 c=0.25$ となる。この式を用いて紅斑紫外放射照

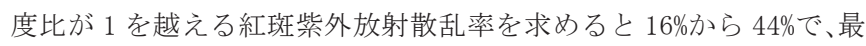
大值は 30\%にある。雲があると広い範囲で快晴時よりも紅斑紫外放 射が大きくなる可能性があることが判った。

\section{3 全天紅斑紫外放射照度と雲量}

図 6 は全天紅斑紫外放射照度と雲量の関係を示す。雲量は天空魚 眼写真から算出した ${ }^{14)}$ 。雲一つない快晴が 0 で、全天が雲に覆われ た曇天が 10 である。本図に使用した測定值は太陽高度 70 度以上、 74 ケースである。雲量が 0 から 3 と低く快晴または晴天の時、紅斑 紫外放射照度比は 0.8 から 1 にあるが、雲量 4 から 7 でばらつきが 最大となり、 7 を超えると急速に減少し、9 寸なわち曇天では 0.3 程 度となる。

\section{4. 天空紅斑紫外放射輝度}

\section{1 天空紅斑紫外放射輝度の測定値}

大量に取得した紅斑紫外放射輝度の測定值から、分析に用いるた めに選択した測定值の条件は、(1)快晴、(2)南中時前後 2 時間、(3)天 空要素高度 18 度以上、(4)太陽・天空要素間各距離 20 度以上、(5) 5 分以内に太陽直達がありかつ周囲に雲が存在、である。快晴、南中 時前後 2 時間の紅斑紫外放射が大きい時間帯を対象としているのは 本研究が紫外放射被曝についての基礎資料を作成することを目的と

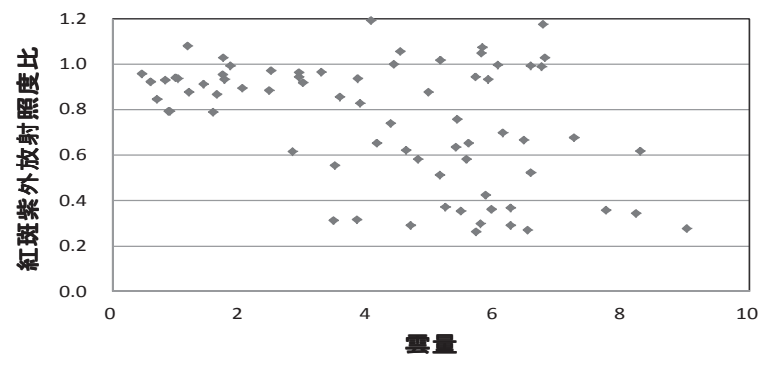

図 6 紅斑紫外放射照度比と雲量

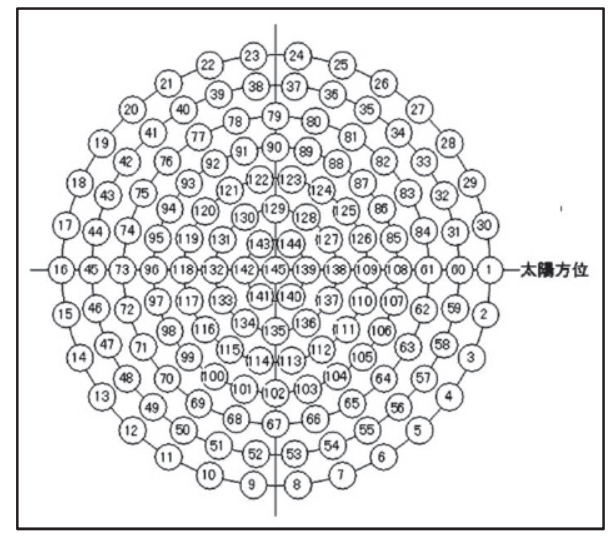

図 7 天空要素番号

しているからである。天空要素高度 6 度の測定值は地物の影響を受 けるためで利用せず、1 8 度以上とした。また太陽・天空要素間角距 離が 20 度以下の場合、太陽及びその近傍の高紅斑紫外放射輝度の影 響を受けるため測定值を使用しなかった。天候については快晴時を 中心としたが、比較のため晴天の測定值も一部含めた。本解析に用 いたデータセットは238、データ数は 34,510 である。

図 7 は電子走查式天空紅斑紫外放射輝度分布測定装置の天空要素 番号で, 円中心は天頂, 外周は地平線である. 天空要素番号が小さ いほど要素高度は低い。天空要素番号 1 から 30 は要素高度 6 度、番 号 31 から 60 は 18 度、番号 61 から 84 は 30 度、番号 85 から 108 は4 42 度、番号 109 から 126 は 54 度、番号 127 から 138 は 66 度、番 号 139 から 144 は 78 度、番号 145 は天頂で 90 度である。

\section{2 天空要素と紅斑紫外放射輝度時間変化}

個々の雲の影響を検討するため図4の(6)、(7)の 2 事例を選択した。 図 8 は 6 月 28 日 12 時 36 分 03 秒から 12 時 42 分 00 秒までの、各天 空要素の紅斑紫外放射輝度の変化である。快晴時の 12 時 39 分 36 秒の紅斑紫外放射輝度と前後の時間における紅斑紫外放射輝度の変 化を示している。前後の時間として 213 秒前、150 秒前、60 秒前、 30 秒後、90 秒後、144 秒後を選んだ。

ここで紅斑紫外放射輝度差 Rr は、時間経過前後の天空要素の紅斑 紫外放射輝度を $\mathrm{R}_{\mathrm{a}}$ 、快晴時の天空要素紅斑紫外放射輝度を $\mathrm{R}_{0}$ とする と、

$$
\mathrm{R}_{\mathrm{r}}=\left(\mathrm{R}_{\mathrm{a}}-\mathrm{R}_{0}\right) / \mathrm{R}_{\mathrm{o}}
$$

の無次元量で表現する注 4)。縦軸 0 は紅斑紫外放射輝度の増減が全く 無かった状態で、1 はもとの倍変化があったことを意味している。

天空要素番号が大きいほど、すなわち天空要素高度が高いほど紅 斑放射輝度の変化が大きい。とくに天空要素番号 85 以上、要素高度 42 度以上で変化が大きい。太陽及び近傍の雲の変化が紅斑紫外放射 輝度に大きな影響を与え、最大 0.8 程度変化している。

天空要素番号 85 以下でも、変化が大きい場所が見られるがこれは 低高度の雲の移動による。図 9 は各時刻の天空魚眼写真である。図 中の黒丸は紅斑紫外放射輝度の変化が大きい位置を示している。213 秒前は太陽とその近傍が、 60,123 秒後には地平線に近い方で変化が 

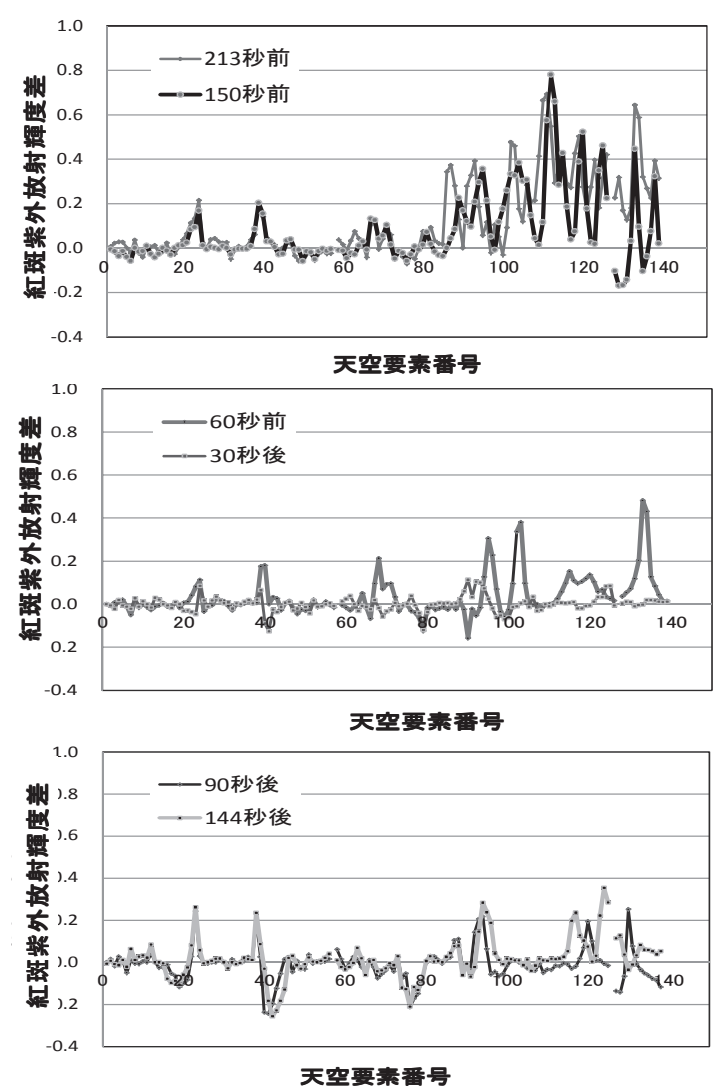

図 8 紅斑紫外放射輝度差と天空要素番号 (6月 28 日)

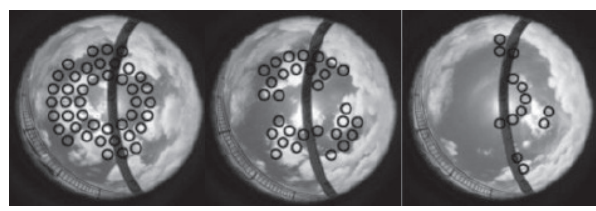

213 秒前 150 秒前 60 秒前

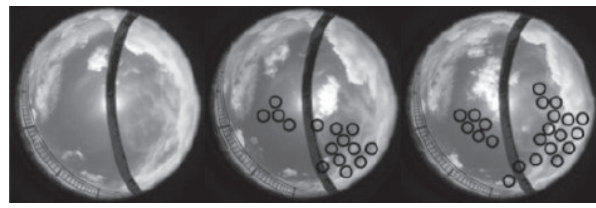

30 秒後 $\quad 60$ 秒後 123 秒後

図 9 天空魚眼写真と経過時間 (6 月 28 日)

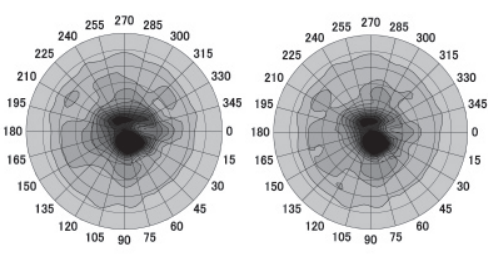

213 秒前

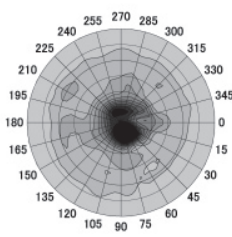

30 秒後

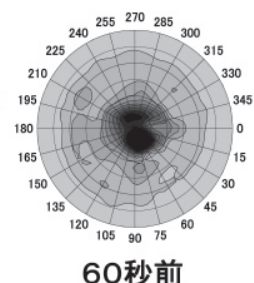

60 秒前

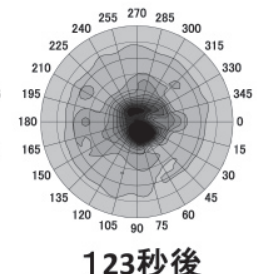

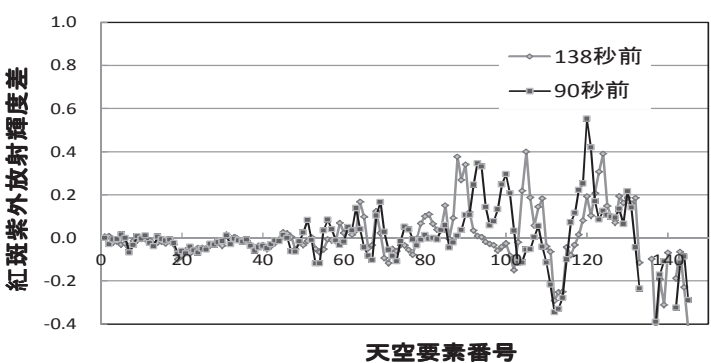
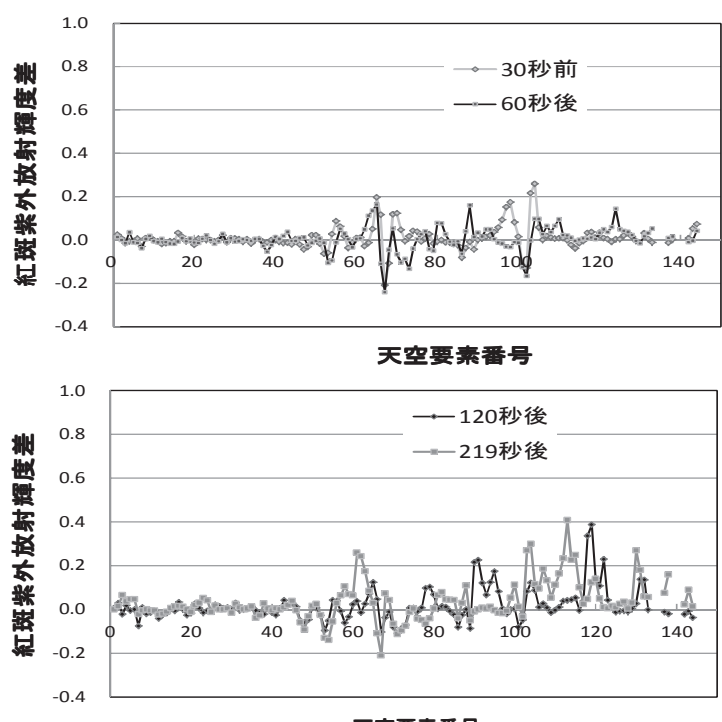

図 11 紅斑紫外放射輝度差と天空要素番号 (6月 29 日)

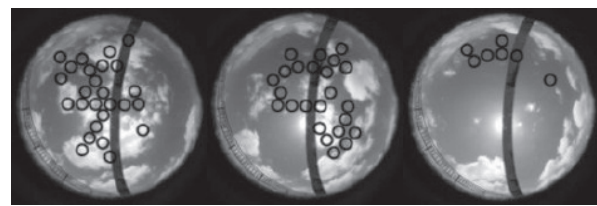

138 秒前 90 秒前 $\quad 30$ 秒前

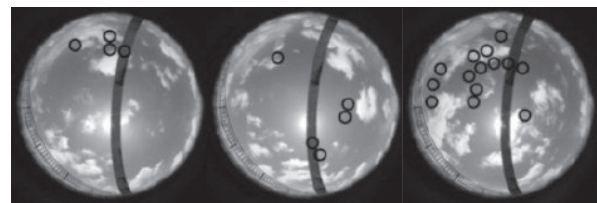

60 秒後 120 秒後 219 秒後

図 12 天空魚眼写真と経過時間 (6 月 29 日)

大きい。時間差が大きいほど、雲の移動も顕著で、 紅玟紫外放射輝度の変化が大きい点が多くなった 図 10 は紅斑紫外放射輝度分布の等值線図と経過 時間である。各時刻と 0 秒との差が紅斑紫外放射 輝度差となる。 0 秒以前の天空要素高度の高い箇 所での変化は図からも読み取れる。

図 11 は 6 月 29 日 13 時 52 分 54 秒から同日 13 時 58 分 51 秒の間の各天空要素番号と紅斑紫外放 射輝度の变化である。快晴の 13 時 55 分 12 秒を基 準にして 138 秒前, 90 秒前, 30 秒前, 60 秒後, 120 秒後, 219 秒後の紅斑紫外放射輝度の变化を示

図 10 紅斑紫外放射輝度分布等值線図と経過時間 
した。6 月 28 日 12 時の測定值と同様の傾向を示し、天空要素高度 の高い方が、変化が大きく, 図 12 の天空魚眼写真を見ても太陽及び 近傍の雲が存在する位置で大きく紅斑紫外放射輝度が変化すること が判る。時間差が大きいほど紅斑紫外放射輝度の変化する点が多く なる。雲が存在すると紅斑紫外放射輝度が増す傾向があるが、雲が 紅斑紫外放射輝度の值に影響する位置, 影響しない位置があり雲が 必ずしも紅斑紫外放射輝度に影響を及ぼすとは限らない。

\section{3 天空紅斑紫外放射輝度と太陽位置の関係}

図 13 は太陽・天空要素間角距離に対する紅斑紫外放射輝度差であ る。太陽・天空要素間角距離が小さく太陽及び近傍と当該天空要素 が近いと、紅斑紫外放射輝度の変化が大きく、角距離 1 以上では少 ない。図 14 は図 13 と異なり角距離 1 以上でも紅斑紫外放射輝度差 は高い。これは太陽から離れた天空要素でも雲の存在によって紅斑 紫外放射輝度は大きく変化するからと考えられる。

図 15、16 は輝度差に対する紅斑紫外放射輝度差の傾向を示す。 輝度差とは、魚眼写真上の輝度最大值を 1 とし、輝度最小值を 0 と した時で、1 とは快晴から厚い雲が出たか、厚い雲が無くなった状 態で、0 とは雲が極めて薄いか小さい状態である。図 $15 、 16$ を見る と、輝度の変化は紅斑紫外放射輝度の変化とは必ずしも一致しない。

本装置のように天空要素のセンサの開口角が 11 度と大きいと、セ ンサのぞむ天空には、広い雲、小さい雲や、厚い雲、薄い雲など様々 な状態が存在し、かつその一部である可能性がある。正確に雲の状 態を把握するのであれば、立体角の狭いセンサを多数並べる必要が ある。

\section{5. 結論}

2012 年 6、7 月の沖縄県宮古島での紅斑紫外放射照度、紅斑紫外 放射輝度の測定と、天空魚眼写真撮影から次の結論が得られた。

(1) 雲が一部に存在する方が、快晴時より紅斑紫外放射照度が大きく なることが、紅斑紫外放射照度比対紅斑紫外放射散乱率特性から明 らかになった。紅斑紫外放射散乱率が 16\%から 44\%で紅斑紫外放射照 度は快晴時を超えることがある。30\%で最大となる。更に雲が増し紅 斑紫外放射散乱率が増すと緩やかに降下寸る。

（2）雲量が 0 から 3 と低く快晴または晴天の時、紅斑紫外放射照度 比は 0.8 から 1 にあるが、雲量 4 から 7 でばらつきが最大となり、 7 を超えると急速に減少し、9 寸なおち曇天では 0.3 程度となる。

（3）太陽・天空要素間角距離が小さく、太陽及び近傍と当該天空要 素が近いと紅斑紫外放射輝度の変化が大きく、角距離 1 以上では紅 斑紫外放射輝度差は少ない。

(4) 時間差が大きいほど紅斑紫外放射輝度の変化する点が多くなる。

雲が存在すると紅斑紫外放射輝度が増寸傾向があるが、雲が紅斑 紫外放射輝度の值に影響する位置, 影響しない位置があり、雲が必 ず紅斑紫外放射輝度に影響を及ぼすとは限らない。雲が天空の一部 に存在する方が、快晴時よりも紫外放射が増加することは以前の研 究から知られていたが、本研究によりその増加原因が一部分明らか にされた。今後、雲の厚み、成分、高さ、広さ、形状の詳細な観測 により、雲による紫外放射の透過・反射を明らかにしていく必要が ある。

今回の研究により快晴時に紫外放射が最も高い訳ではなく、雲が
一部に存在する方が、紫外放射が高くなることが判ったが、その割 合は 2 割以下で、夏季、太陽南中、快晴時の紅斑作用による日焼け の発生 20 分が 17 分に短縮されるに過ぎない。このような短時間で 急速に変化する天候での紫外放射被曝防御法は、サンスクリーンな ど個人的防御とこまめに身近な日陰に入る以外無い。サンスクリー ン、日傘、日除け、日陰などの本格的な紫外線防御が必要であるこ とには変わりない。

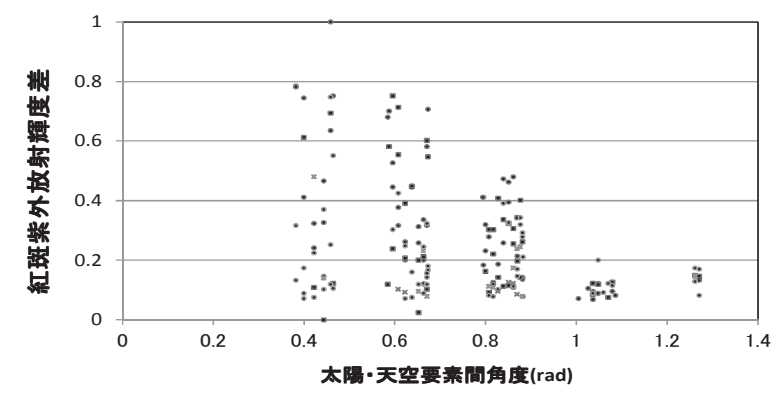

図 13 紅斑紫外放射輝度差と太陽・天空要素間角距離(6月 28 日)

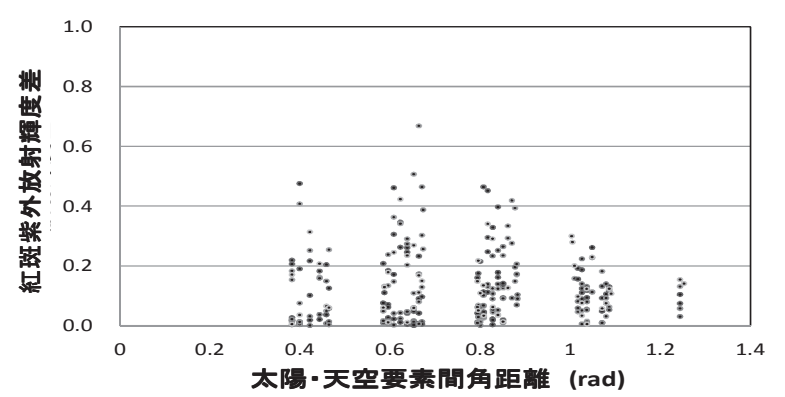

図 14 紅斑紫外放射輝度差と太陽・天空要素間角距離 (6 月 29 日)

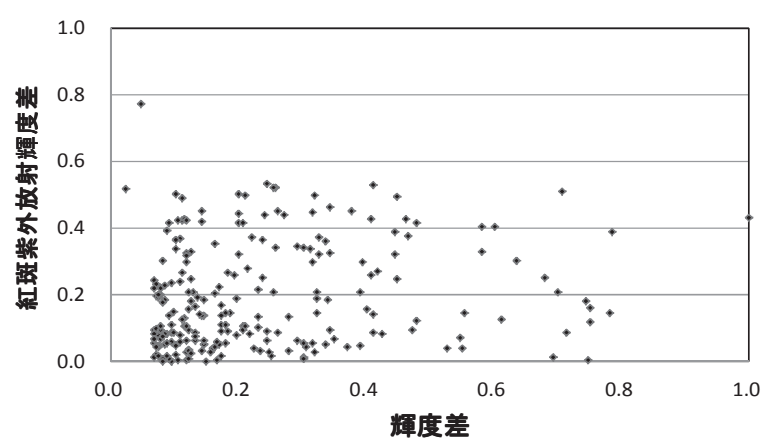

図 15 紅斑紫外放射輝度差と輝度差 (6 月 28 日)

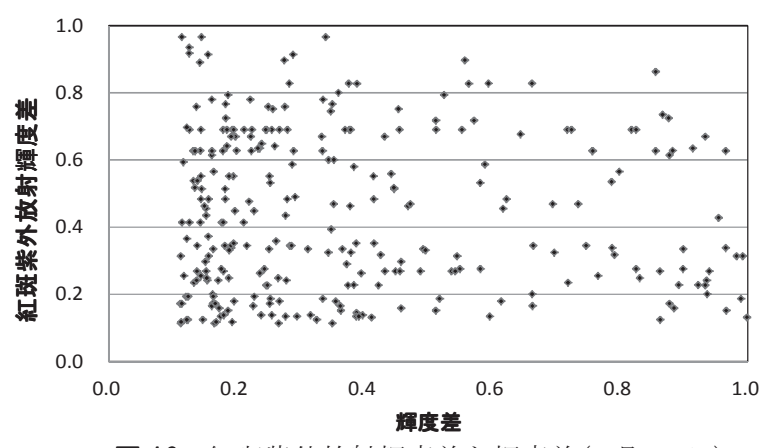

図 16 紅斑紫外放射輝度差と輝度差 (6 月 29 日) 


\section{注}

注 1) 紅斑紫外放射: 地表面の波長別紫外放射束密度に CIE 作用曲線を乗じて 波長 $250 \mathrm{~nm}$ から $400 \mathrm{~nm}$ まで積分して算出する。本研究では、紅斑作用曲線 の感度を持つセンサを用いることで測定している。紅斑紫外放射照度、紅 斑紫外放射輝度は、同方法で求めた照度、輝度を指す。

注 2) 紅斑紫外放射照度比: 測定期間中の夏至、太陽南中、雲無し快晴時の最 大紅斑紫外放射照度で各時刻の紅斑紫外放射照度を除した值である。分母 として、参考文献 4)の雲無し天空状況下で観測される参照スペクトルから 算出した標準紫外域日射量を用いる方法と、本研究で紹介した参考文献 1) の帯域センサによる測定值を用いる方法があるが、ここでは後者を採用し た。無次元量である。

注 3) 紅斑紫外放射散乱率：天空紅斑紫外放射照度を全天紅斑紫外放射照度で 除した值を百分率で表現した。散乱の割合を示す值で、参考文献 4) 内で、 日射散乱率と定義されたものを紅斑紫外放射に適用した。文献内では 0 か ら 1 で記されているが、本稿では百分率で表し 0 から 100 とした。

注 4) 紅斑紫外放射輝度差 : 雲の存在による紅斑紫外放射輝度の変化を表すた めに、定義した量である。時間経過前後の天空要素の紅斑紫外放射輝度か ら、快晴時の天空要素紅斑紫外放射輝度を差し引いた值を、後者の值で除 して変化分を表現している。無次元化量である。

\section{参考文献}

1) Jeral G.Estupinan, Sethu Raman, Gennaro H.Crescenti, John J. Streicher, William F. Barnard : Effects of clouds and haze on UV-B radiation,Journal of Geophysical Research, Vol.101, No.D11 pp.16,807-16,816, July1996

2) J. Crawford, R. E. Shetter, B. Lefer, C. Cantrell, W. Junkermann, S. Madronich, and J. Calvert: Cloud impacts on UV spectral actinic flux observed during the International Photolysis Frequency Measurement and Model Intercomparison, JOURNAL OF GEOPHYSICAL RESEARCH, VOL. 108, NO.
D16, 8545, doi:10.1029/2002JD002731, 2003

3）新聖子,垂水弘夫,久保猛志 : 生体影響紫外線 DUV の天気及び雲量・出現高さ・雲形に 基づく天空状態別解析,日本建築学会環境系論文集,第 580 号,pp.69-75,2004.6

4) 高野松美：地上到達紫外域日射に及ぼす雲の影響, 高層気象台彙報, 第 66 号, pp. 39-46, 2006

5)Philipp Weihs, Ann R. Webb, Samantha J. Hutchinson, Glenn W. Middleton: Measurements of the diffuse UV sky radiance during broken cloud conditions, Journal of Geophysical Research, Vol.105 No.D4, pp.4937-4944, 2000.2

6) Christopher Kuchinke, Kurt Fienberg, Manuel Nunez : The Angular Distribution of UV-B Sky Radiance under Cloudy Conditions: A Comparison of Measurements and Radiative Transfer Calculations Using a Fractal Cloud Model, J. Appl. Meteor., 43, pp.751-761 , 2004.5

7）井川憲男, 永村一雄 : 天空輝度・放射輝度分布を推定するAll Sky Model の改良, 日本 建築学会計画系論文集 第 77 巻第 673 号 pp. 121-127 2012.3

8）中山哲士, 石野久彌 : 放射輝度分布の不規則性と雲の状態による要因 日射の直散分 離に影響を及ぼす気象要素の特性研究(その 2), 日本建築学会環境系論文集 第 611 号 pp. 21-27 2007. 1

9) Philipp Weihs, Ann R. Webb, Samantha J. Hutchinson, Glenn W. Middleton: Measurements of the diffuse UV sky radiance during broken cloud conditions, Journal of Geophysical Research, Vol. 105 No. D4, , p. 4938 2000.2

10）川西利昌, 前田直樹, 大塚文和 : 電子走査式天空放射輝度測定装置を用いた沖縄県石 垣島真栄里海岸の天空及び地物紅斑紫外放射輝度分布測定, 日本建築学会環境系論文 集, 第 77 巻第 678 号, pp. 707-711, 2012.8

11)川西利昌, 大塚文和 : 沖縄県石坦島における天空の状態と天空紅斑紫外放射輝度に関 寸る研究, 日本建築学会環境系論文集, 第 78 巻, 第 685 号, pp. 249-254, 2013. 3

12) Jeral G. Estupinan, Sethu Raman, Gennaro H. Crescenti, John J. Streicher, William F. Barnard : Effects of clouds and haze on UV-B radiation, Journal of Geophysical Research, Vol.101, No.D11 p. 16, 809 , 1996.7

13）高野松美：地上到達紫外域日射に及ぼす雲の影響, 高層気象台彙報, 第 66 号, p. 42, 2006

14) 嘉門隆史, 上谷芳昭, 吉田治典, 西尾信寛 : ビデオ測色法による雲の観測に関る基礎的 研究, 平成 17 年度日本建築学会近畿支部研究報告集, pp. 9-12, 2005

(2013年 4 月 9 日原稿受理, 2013年 7 月 31 日採用決定) 